\title{
ANALYSIS RELATED TO JUDGES' CONSIDERATIONS IN THE IMMEDIATE DECISION OF CRIMINAL ACTIONS AGAINST CHILDREN
}

\author{
Iskandar $^{1^{*}}$, Ariza Umami ${ }^{2}$ Dilla Fadilla ${ }^{3}$ \\ ${ }^{1,2,3}$ Universitas Muhammadiyah Metro \\ E-mail: ${ }^{1)}$ iskandarmt51@gmail.com, ${ }^{2)}$ arizaumami86@gmail.com, ${ }^{3)}$ fadillad813@gmail.com
}

\begin{abstract}
Analysis of Judges' Considerations in Imposing Decisions on Immoral Crimes Against Children and implementation of decisions related to Law Number 23 of 2002 concerning Child Protection Article 81 Paragraph (2). The purpose of this paper is to analyze the judge's considerations in deciding cases of immoral crimes against children. This research method uses an empirical juridical approach which is carried out by interviewing several respondents or related sources. The results of the study show that when judges are deciding on criminal cases involving children, they take into account both items that charge and things that relieve the issue. However, the implementation of the verdicts in criminal cases involving children is carried out in line with the Operational Standards of General Criminal Procedure, as well as with the Children's Criminal Justice System. There are three different types of decisions that can be made under the provisions of the KUHAP, namely: court decisions in the form of a judgment (Veroordeling), court decisions in the form of a redeeving of all charges (Vrijspraak), and court decisions in the form of freedom from all forms of law (Onslag van all rechtsvervolging).
\end{abstract}

Keywords: Judge's Consideration, Immoral Crime, Law Enforcement

\section{INTRODUCTION}

As the nation's future and the next generation of its ideals, children require protection in order to ensure their survival and growth and development on all levels, including the mental, physical, and social. All children have the right to protection from acts of violence, discrimination, and exploitation of civil rights and freedoms that can interfere with their physical, spiritual, and social development; otherwise, they risk being harmed (Nashriani, 2012). The irony is that children are increasingly targets of crime, and as such, they should be provided with protection. As a major social problem, sexual crimes against children are on the rise, and the prevalence of criminal acts of sexual violence against children has a negative impact on the effectiveness of the law in our legal system.

Immoral violence can be committed in a variety of ways and using a variety of tools and methods. In accordance with the provisions of the Convention on the Rights of the Child (1989) and its additional protocol, the CRC (option protocol Convention on the Rights of the Child) states that the types of violence that occur to children are classified into four categories: physical violence, sexual violence, emotional violence, and sexual violence. Commercial sexual exploitation, which includes the selling of minors, child prostitution, and child pornography, are examples of immoral forms of violence. In other words, immoral violence includes sexual mistreatment in the form of sex, or through the vaginal area, penis, 
orally, with tools, up to and including showing the genitals, sexual coercion, sodomy, oral sex, masturbation, and sexual harassment, as well as incest, which should no longer be considered a minor issue because the social situation is becoming increasingly serious. A considerable increase in occurrences of sexual violence against children was observed between 2016 until 2019, according to data from the Witness and Victim Protection Agency (LPSK). There were 350 cases of sexual abuse against children reported in 2019, 200 cases of sexual violence against children reported in 2018, 180 cases of sexual violence against children reported in 2017, and 30 cases of sexual violence against children reported in 2016.

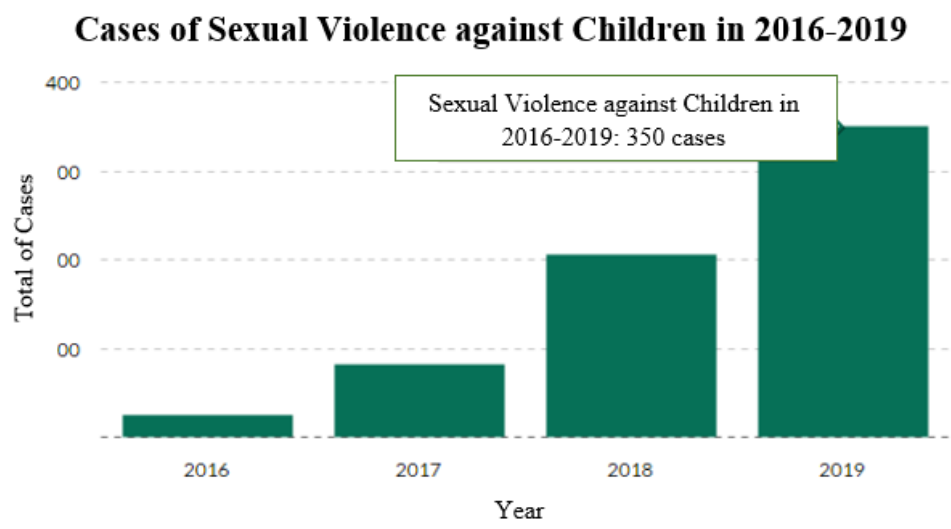

Source: Liputan6.com

Figure 1 Cases of Sexual Violence against Children in 2016-2019

The data in the above table demonstrates that immoral crimes against minors are on the rise. In addition to the psychological consequences of child abuse, the act of sexual harassment itself can cause stress, depression or mental shock. Feelings of guilt may arise, and the victim may be afraid of communicating with others or even being ridiculed by the public. He may have nightmares, have trouble sleeping, have insomnia, be afraid of certain objects or places, or have issues related to self-esteem. Apart from that, the victim suffers from the physical, emotional/psychological, as well as the real consequences of acts of sexual abuse/violence. Most of the real consequences of acts of sexual abuse/violence experienced by children include sexual diffusion, somatic complaints, pregnancy and unwanted things, chronic pain, and sexually transmitted diseases. Clearly, the consequences of this crime of violence against children and immorality have a negative impact on the future generation of society, and as a result, a realistic approach to dealing with it both de facto and de jure is required.

\section{RESEARCH METHOD}

The method of empirical juridical analysis is the research method that was employed in the problem-solving process. 'Empirical' refers to something that is factual. An attempt to address the topic under investigation with an actual legal nature and in conformity with the facts of life in society is meant by the empirical method. For this study, secondary and primary data were combined by merging legal studies books connected to this research with laws and facts gathered in the field to create a comprehensive set of information. Researchers in the field must visit the community and communicate with members of the community as part of their research (Hadikusuma, 1995). This research was carried out at the Metro District 


\section{POLICY, LAW, NOTARY AND REGULATORY ISSUES (POLRI) \\ VOLUME 1 ISSUE 1 (2022)}

Attorney's Office and the Metro District Court, which serve as law enforcement agencies in the pursuit of justice. The purpose of conducting this research is to obtain an understanding of the legal analysis surrounding immoral offenses against minors in the city of Metro.

\section{RESULT AND DISCUSSION}

The protection and welfare of children necessitates the support of institutions, as well as rules and regulations that can ensure their implementation and enforcement. The definition of a child according to the Convention on the Rights of the Child (Convention on the Right of the Child) is not significantly different from the definition of a child according to several other laws. According to the Convention on the Rights of the Child, a child is defined as a person who has not reached the age of 18 (eighteen) years unless otherwise provided for by the Convention on the Rights of the Child (Convention on the Right of the Child). When it comes to minors, the law applies since maturity is acquired earlier. In Law No. 11 of 2012 concerning the Juvenile Criminal Justice System, it is stated that children who are victims of criminal acts, hereinafter referred to as child victims, are children who are not yet 18 (eighteen) years old who experience physical, mental and/or economic losses caused by caused by a crime.

"Law of the Republic of Indonesia Number 11 of 2012 concerning the Juvenile Criminal Justice System" is the entire process of resolving cases of children in conflict with the law, from the investigation stage to the guidance stage after serving a crime. Children who are victims of criminal acts are called child victims. Child victims themselves are children who experience physical, mental, and/or economic losses caused by criminal acts.

The parties involved in the juvenile criminal justice process are Investigators, Public Prosecutors, Judges, Community Counselors and Social Workers.

1. Investigators are Child Investigators

2. Public Prosecutor is Child Public Prosecutor

3. Judge is a Child Judge

4. Community Advisor is a functional law enforcement official who carries out community research, guidance, supervision, assistance to children inside and outside the criminal justice process.

5. Social worker is someone who works in both government and private institutions who have the competence and profession of social worker and concern in social work obtained through education, and or experience of social work practice to implement social problems.

Investigation processes up to guidance after sentencing

Investigations can only be carried out by investigators who have been determined by the decision of the Chief of Police or other officials who have been directly appointed by the Head of the Police of the Republic of Indonesia, while in public prosecutions are determined based on the Decree of the Attorney General or other officials who have been appointed by the Attorney General. In the investigation of children's cases, investigators must ask for considerations or suggestions from the community advisor after the crime is reported or reported, then the Community Research Center is obliged to submit the results of the investigation to the community no later than 3 days counted from the investigator's request.

When investigating child victims, investigators are required to first obtain social reports from social workers or social welfare workers after the crime has been reported, and 
then when investigating children who are proposed as children in legal conflict (ABH) at the level of investigation, prosecution, and examination of children's cases in court, they are required to first make diversion before proceeding with the investigation. For the purposes of this definition, diversion is defined as the process of transferring the settlement of a child abuse case from within the criminal justice system to outside the criminal justice system under the following conditions:

1. Was sentenced to less than seven (seven) years in prison.

2. And certainly not a recurrence of a crime

In addition to these provisions, it also applies to children who have been accused of committing a crime which is punishable by imprisonment for under 7 (seven) years or more in the form of subsidiary, alternative, cumulative or combined charges in accordance with Article 7 PERMA Number 42014 concerning Guidelines for Implementing Diversion in the Juvenile Criminal Justice System.

The process of examining court hearings on children in the first level is only carried out by a single judge, the Chairperson of the Court in the process of examining cases against children with a panel of judges in the case of a criminal offense punishable by imprisonment of 7 (seven) years or more difficult to prove. Judges in examining cases of child crimes in juvenile courts are declared closed to the public except for the reading of decisions. Furthermore, in the child trial process in accordance with Article 55 of Law Number 11 of 2012 concerning the Juvenile Criminal Justice System, the Panel of Judges is obliged to order the parent/guardian or other legal aid provider in the event that the parent, guardian or companion is not present, the trial is continued with the accompanying by an advocate or other legal aid provider and/or community advisor.

Children in conflict with the law whose age is fourteen years and above can be given criminal penalties with various forms of crime as stipulated in Article 71 of the Law of the Republic of Indonesia Number 11 of 2012 concerning the Juvenile Criminal Justice System, which are as follows:

1. The main crime consists of: warning, conditional punishment (guidance in institutions, community service, supervision), job training and coaching in institutions and prisons

2. Additional punishment in the form of deprivation of profits obtained from criminal acts, fulfillment of customary obligations.

In the judge's decision at the first level, children who are in conflict with the law and the public prosecutor can certainly take legal action, namely appeal, cassation and review.

The execution was carried out based on the Rules of the Attorney General of the Republic of Indonesia concerning Standard Operating Procedures (SOP) for the Handling of General Crime Cases. Article 48 Implementation of the Court's Decision which reads:

1. "The implementation of court decisions that have obtained legal force will still be carried out by the prosecutor based on an order from the head of the district attorney who handles the case

2. A warrant regarding the implementation of a court decision that has permanent legal force is issued no later than 3 (three) days from the receipt of the court's decision.

3. In the event that the verdict is acquitted of all charges or acquitted of all legal charges for which the defendant is detained, the prosecutor on the same day asks for a copy or excerpt of the court's decision and immediately releases the defendant from detention. 


\section{POLICY, LAW, NOTARY AND REGULATORY ISSUES (POLRI) \\ VOLUME 1 ISSUE 1 (2022)}

4. In the event that the convict applies for clemency or extraordinary legal remedies in the form of a review, the implementation of the court's decision shall be based on more specific provisions regarding clemency and judicial review.

5. The implementation of court decisions can be carried out by a prosecutor or in the form of a team that is adapted to the needs and circumstances by involving administrative/administrative staff.

6. In the event that the execution of a court decision is carried out by a team, one team member is appointed as the team leader by taking into account the competence in question

7. The appointment of prosecutors to carry out court decisions prioritizes Public Prosecutors who are appointed as the Prosecution Team and changes can be made in accordance with the policies of the Work Unit Leaders

8. The implementation of the court's decision is carried out completely (corporal punishment, fines, evidence, restitution and court fees) no later than 7 (seven) days

9. Administrative/administrative officers who are administratively responsible for the implementation of court decisions

10. In the case of a death penalty decision, its implementation is based on statutory provisions."

\section{Legal Analysis of Cases of Immoral Crimes against Children}

Efforts at consistent law enforcement must continue to be pursued by law enforcement officers, including those from the police and prosecutor's office, who function as investigators in every crime that occurs in society, before passing the case on to the judge, who then makes the final judgment. When law enforcement officers actually position themselves in accordance with the mandate of the law, law enforcement on a continuous basis will be carried out properly and effectively. In a free and open society, the role of the law is to enforce truth and justice, which is to say, to uphold the truth and to uphold the rule of law. As long as law enforcement is conducted without discrimination or favoritism, and there is no discrimination, or if the enforcement is not one-sided or impartial, this can be achieved. Law enforcement carried out in Metro City relating to the implementation of decisions has been consistent with the criminal law enforcement system, which affirms the division of responsibilities and authorities between the ranks of law enforcement officers of criminal procedure (Functional Differentiation) and the criminal justice system, which regulates how the enforcement of criminal procedure law is carried out (Integrated Criminal Justice system). So as to create a conducive situation in the life of the community.

Provisions regarding judges' considerations are regulated in Article 197 paragraph (1) letter $\mathrm{d}$ of the Criminal Procedure Code which states that "Considerations are compiled in brief regarding the facts and circumstances along with the evidence obtained from examination at trial which is the basis for determining the guilt of the accused. ". This was also put forward by Lilik Mulyadi (2007) who said that:

The Judge's Legal Basis regarding Judges' Considerations is regulated in Article 197 paragraph (1) letter $\mathrm{d}$ of the Criminal Code which states that "Considerations are compiled in a nutshell regarding facts and circumstances along with evidence obtained from examinations at trial which are the basis for determining guilt of the defendant". 
During the decision-making process, the judge must actively ask questions and allow opportunity for the defendant, who is represented by an attorney, to challenge witnesses as well as the public prosecutor on the merits of the case. All are meant to reveal material reality, and in the end, it is the judge who bears ultimate responsibility for everything that is determined (Hamzah, 2000).

When a judge is faced with a case, a thought process takes place within him to then give his decision on the following matters: (Soedarto, 1986)

1. The decision regarding the incident, namely whether the defendant has committed the act that has been accused of him.

2. The decision regarding the sentence, namely whether the act committed by the defendant is a crime and whether the defendant is guilty and can be punished.

3. The decision regarding the punishment, namely the defendant can indeed be sentenced.

The judge of the Metro District Court, in deciding the case, considered that in order to punish the defendant, he must fulfill at least 2 pieces of evidence as specified in the Criminal Procedure Code. The judge's considerations in deciding cases of immoral crimes are guided by Article 81 paragraph (2) of the Republic of Indonesia Law no. 17 of 2016 concerning the Stipulation of Government Regulation in Lieu of Law Number 1 of 2016 concerning the Second Amendment to Law Number 23 of 2002 concerning Child Protection. In the case of immoral crimes against children, the judge gave a decision that was included in the Rehabilitation and Restitution process.

Restitution itself is in Article 1 Number 13 of the PTPPO Law explaining that Restitution is the payment of compensation charged to the perpetrator based on a court decision that has permanent legal force for material and/or immaterial losses suffered by the victim or his heirs.

Elucidation of Article $71 \mathrm{D}$ of the Child Protection Law provides a definition that restitution is:

"The payment of compensation charged to the perpetrator based on a court decision that has permanent legal force for material and/or immaterial losses suffered by the victim or his heirs. Especially for children who are in conflict with the law who are entitled to restitution are children of victims".

Furthermore, the Legal Basis for Implementing Court Decisions are:

a. Article 1 number 6 letter a KUHAP

b. Article 270 to Article 276 of the Criminal Procedure Code

The provisions in the Criminal Procedure Code are general in nature, so that in their implementation they must still be adjusted to the provisions of special events from various other laws and regulations (lex specialist derogate legi generali).

c. Article 30 Paragraph (1) letter b of Law Number 16 of 2004 concerning the Prosecutor's Office of the Republic of Indonesia

d. Article 54 paragraph (1) of Law Number 48 of 2009 concerning Judicial Power.

e. Law Number 2/PNPS/ 1964 concerning Procedures for Implementing the Death Penalty handed down by Courts in General and Military Courts 


\section{POLICY, LAW, NOTARY AND REGULATORY ISSUES (POLRI) \\ VOLUME 1 ISSUE 1 (2022)}

f. Regulation of the Attorney General of the Republic of Indonesia Number PER036/A/JA/09/2011, dated 21 September 2011, Article 48 concerning the SOP for the Pidum.

Based on the provisions of the Criminal Procedure Code, there are 3 types of decisions:

1. Court Decisions in the form of Sentencing (Veroordeling)

The sentencing decision or Veroordeling is regulated in Article 193 paragraph (1) of the Criminal Procedure Code with the editorial that: "If the court stated that the defendant is guilty of committing the crime he is accused of, the court shall impose a sentence".

2. Court decision in the form of acquittal from all charges (Vrijspraak)

The provisions of Article 191 paragraph (1) of the Criminal Procedure Code, regarding the acquittal/Vrijspraak decision may be imposed by the Panel of Judges due to:

- From the results of the examination in court

- The defendant's guilt for the actions he was accused of was not legally and convincingly proven according to law.

3. Court decisions in the form of being free from all forms of lawsuits (Onslag van alle rechtsvervolging)

In accordance with the provisions of Article 191 paragraph (2) of the Criminal Procedure Code, it explicitly regulates "Decision on waiver from all lawsuits" or "Onslag van alle rechtsvervolging". In the provisions of this article, the decision to release from all lawsuits can be formulated editorially that:

"If the court stated that the act that has been charged against the defendant is proven, but the act does not constitute a criminal act, then the defendant is dismissed from all charges."

\section{CONCLUSION}

In light of the findings and discussion of the research, it is possible to conclude that when judges are deciding on criminal cases involving children, they take into account both items that charge and things that relieve the issue. However, the implementation of the verdicts in criminal cases involving children is carried out in line with the Operational Standards of General Criminal Procedure, as well as with the Children's Criminal Justice System. There are three different types of decisions that can be made under the provisions of the KUHAP, namely: court decisions in the form of a judgment (Veroordeling), court decisions in the form of being free from all forms of lawsuits (Vrijspraak), and court decisions in the form of freedom from all forms of law (Onslag van all rechtsvervolging).

\section{REFERENCES}

Hadikusuma, H. (1995). Pembuatan Kertas Kerja atau Skripsi Ilmu Hukum. Mandar Maju. Hamzah, A. (2000). Hukum Acara Pidana Indonesia. In Hukum Acara Pidana Indonesia. Mulyadi, L. (2007). Putusan Hakim dalam Hukum Acara Pidana. PT Citra Aditya Bakti. Nashriani. (2012). Perlindungan Hukum Pidana Anak di Indonesia. :PT Raja Grafindo. Soedarto. (1986). Kapita Selekta Hukum Pidana. Alumni. Law Number 11 of 2012 concerning the Juvenile Criminal Justice System 
Law of the Republic of Indonesia Number 35 of 2014 on amendments to Law Number 23 of 2002 concerning Child Protection

Law Number 16 of 2004 concerning the Prosecutor's Office Article 2 Paragraph (1) of the Prosecutor's Law 